\title{
Aspirin as a potential modality for the chemoprevention of breast cancer: A dose-response meta-analysis of cohort studies from 857,831 participants
}

\author{
Liming Lu ${ }^{1}$, Leiyu Shi ${ }^{2}$, Jingchun Zeng ${ }^{3}$ and Zehuai Wen ${ }^{1,4}$ \\ ${ }^{1}$ The Second Affiliated Hospital of Guangzhou University of Chinese Medicine, Guangdong Provincial Hospital of Chinese \\ Medicine, Guangzhou, China \\ ${ }^{2}$ Department of Health Policy and Management, Bloomberg School of Public Health, Johns Hopkins University, Baltimore, \\ MD, USA \\ ${ }^{3}$ Guangzhou University of Chinese Medicine, Guangzhou, China \\ ${ }^{4}$ National Center for Design Measurement and Evaluation in Clinical Research, Guangzhou University of Chinese Medicine, \\ Guangzhou, China
}

Correspondence to: Zehuai Wen, email: wenzh@gzucm.edu.cn

Keywords: aspirin, breast cancer, dose-response Meta-analysis

Received: January 17, $2017 \quad$ Accepted: February 20, $2017 \quad$ Published: March 17, 2017

Copyright: Lu et al. This is an open-access article distributed under the terms of the Creative Commons Attribution License 3.0 (CC BY 3.0), which permits unrestricted use, distribution, and reproduction in any medium, provided the original author and source are credited.

\section{ABSTRACT}

Background: Previous meta-analyses on the relationship between aspirin use and breast cancer risk have drawn inconsistent results. In addition, the threshold effect of different doses, frequencies and durations of aspirin use in preventing breast cancer have yet to be established.

Results: The search yielded 13 prospective cohort studies $(\mathrm{N}=857,831$ participants) that reported an average of 7.6 cases/1,000 person-years of breast cancer during a follow-up period of from 4.4 to 14 years. With a random effects model, a borderline significant inverse association was observed between overall aspirin use and breast cancer risk, with a summarized $R R=0.94(P=0.051,95 \%$ CI $0.87-$ 1.01). The linear regression model was a better fit for the dose-response relationship, which displayed a potential relationship between the frequency of aspirin use and breast cancer risk ( $R R=0.97,0.95$ and 0.90 for 5, 10 and 20 times/week aspirin use, respectively). It was also a better fit for the duration of aspirin use and breast cancer risk ( $R R=0.86,0.73$ and 0.54 for 5,10 and 20 years of aspirin use).

Methods: We searched MEDLINE, EMBASE and CENTRAL databases through early October 2016 for relevant prospective cohort studies of aspirin use and breast cancer risk. Meta-analysis of relative risks (RR) estimates associated with aspirin intake were presented by fixed or random effects models. The dose-response meta-analysis was performed by linear trend regression and restricted cubic spline regression.

Conclusion: Our study confirmed a dose-response relationship between aspirin use and breast cancer risk. For clinical prevention, long term ( $>5$ years) consistent use (2-7 times/week) of aspirin appears to be more effective in achieving a protective effect against breast cancer.

\section{INTRODUCTION}

Worldwide, breast cancer comprises $23 \%$ of total cancer cases and causes $14 \%$ of cancer related deaths in women [1]. There are many risk factors for breast cancer including environmental, hereditary, dietary and socioeconomic. However, the underlying mechanism behind breast cancer is not fully understood $[2,3]$.

Aspirin may inhibit the cancer-initiating stage through the cyclooxygenase (COX) enzyme system. The production of prostaglandins, cyclic adenosine monophosphate (cAMP), aromatase activity and cell proliferation in breast cancer cells 
are stimulated by COX-2. Aspirin may block the COX2 enzyme to inhibit this process [4]. Therefore, aspirin is a potential agent for the chemoprevention of breast cancer. Furthermore, it has been confirmed that aspirin use is associated with the risk of colorectal, ovarian and prostate cancer [5-8].

However, several epidemiological studies assessing the relationship between breast cancer risk and aspirin use have drawn inconsistent conclusions [5-8]. The frequencyrisk, dose-risk and duration-risk relationships still need to be explored. Recently, several large cohort studies have explored the relationship between aspirin intake and breast cancer risk $[9,10]$. A sufficient number of cohort studies have been conducted in recent years, which have also benefited our probe of a dose-response relationship. This study aims to 1) test whether there is a dose-response relationship between aspirin use and breast cancer risk; 2) confirms the optimal frequency, duration and dose of aspirin intake in preventing breast cancer, and guide the rational application of aspirin in clinic.

\section{RESULTS}

\section{Literature search}

686 unique citations were retrieved: 441 from Medline, 148 from Embase and 97 from CENTRAL. Of these, 604 were excluded after identification, screening and eligibility processes, based on titles or abstracts, leaving 82 citations for full-text review. Of the 82 remaining citations, 69 were excluded and 13 were included. The article selection process is presented in Figure 1.

\section{Characteristics}

Characteristics of the 13 selected cohort studies are presented in Table 1. Included studies were published between 2002 and 2015, and the number of participants per study ranged from 23,708 to 127,383 , for a total of 857,831 (average 7.6 cases/1,000 person-years of breast cancer). 10 studies were conducted in the United States, 1 in the Netherlands, 1 in Denmark and 1 in the United Kingdom. Breast cancer was screened along with medical records and pathology reports, or through linkages with cancer registries in 12 studies (one study had no report of this). Aspirin use was measured from self-reported data in 10 studies, and computer assisted telephone interviews in 1 study (1 study had no reporting of this). Follow-up duration ranged from 4.4 to 14 years. 11 of those studies had good quality with an NOS score $\geq 7$, while only two studies' NOS ratings (Harris RE-2003 [33] and Kim S-2015 [16]) were less than 7.

Most risk measures were adjusted for age (12 studies), health history (9 studies), body mass index (BMI) (9 studies), education (6 studies), use of hormone therapy (6 studies) or alcohol consumption (6 studies); less
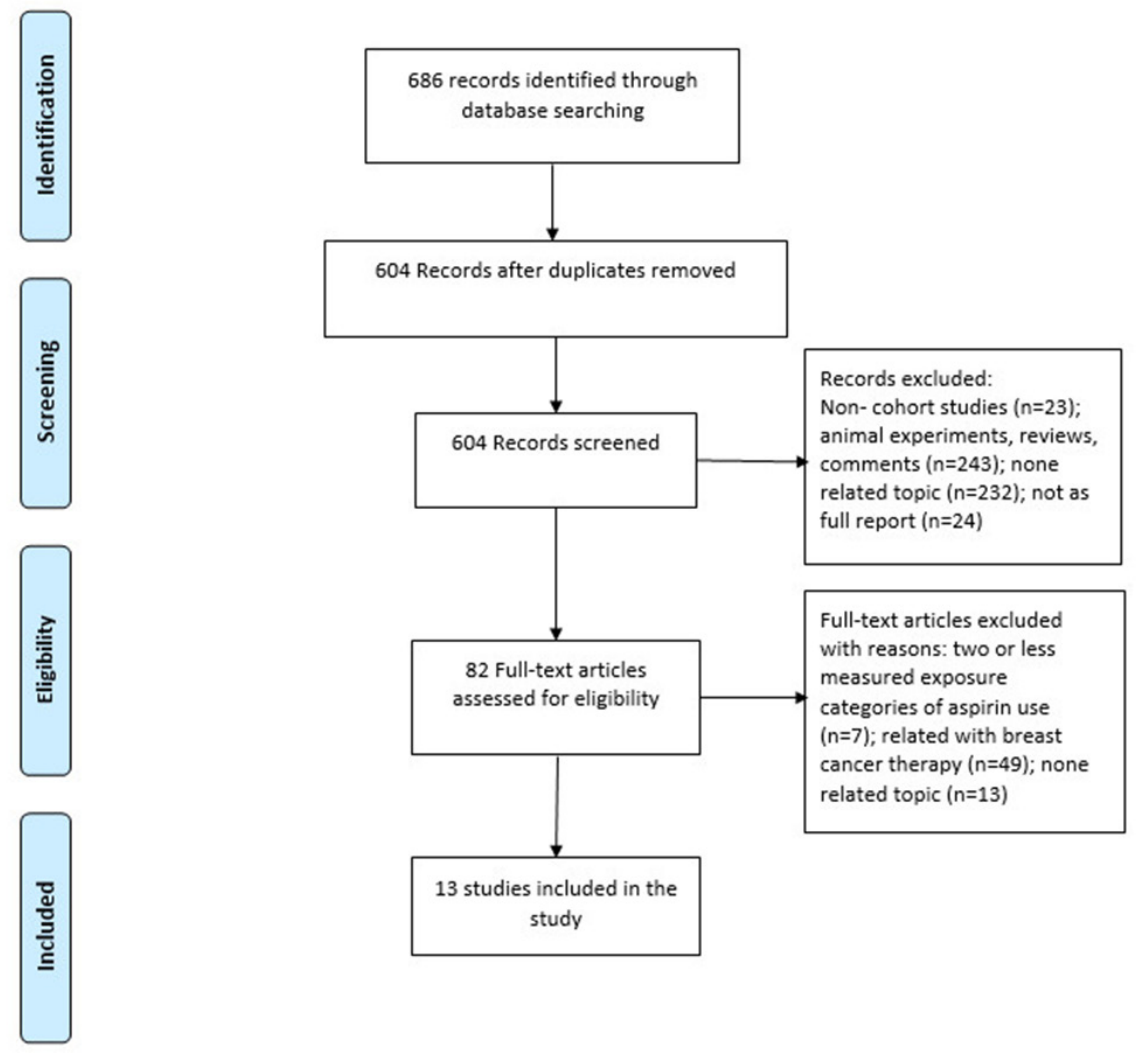

Figure 1: Flow chart of reports selection. 
Table 1: Characteristics of studies included in our study

\begin{tabular}{|c|c|c|c|c|c|c|c|c|}
\hline Source & Location & $\begin{array}{c}\text { Cohort } \\
\text { Designation }\end{array}$ & $\begin{array}{l}\text { Total No. } \\
\text { of Patients }\end{array}$ & $\begin{array}{c}\text { Breast } \\
\text { cancer } \\
\text { incidence } \\
\text { (Cases/1000 } \\
\text { Person- } \\
\text { Years) }\end{array}$ & $\begin{array}{l}\text { Aspirin Use } \\
\text { Measure and } \\
\text { assessment } \\
\text { periods }\end{array}$ & $\begin{array}{c}\text { Breast Cancer } \\
\text { Screening Method }\end{array}$ & $\begin{array}{l}\text { Maximum } \\
\text { Follow- } \\
\text { up, y }\end{array}$ & NOS \\
\hline $\begin{array}{l}\text { Jacobs } \\
\text { EJ-2005 } \\
{[11]}\end{array}$ & $\begin{array}{l}\text { United } \\
\text { States }\end{array}$ & $\begin{array}{l}\text { Cancer } \\
\text { Prevention } \\
\text { Study II } \\
\text { Nutrition } \\
\text { Cohort }\end{array}$ & 77413 & 5.5 & $\begin{array}{l}\text { Patient } \\
\text { reported: dose, } \\
\text { frequency, } \\
\text { duration; } \\
\text { baseline and } \\
\text { follow-up }\end{array}$ & $\begin{array}{l}\text { Initially by patient } \\
\text { report, follow-up by } \\
\text { questionnaires and } \\
\text { subsequently } \\
\text { verified medical } \\
\text { record or through } \\
\text { linkage with state } \\
\text { registries }\end{array}$ & 10 & 8 \\
\hline $\begin{array}{l}\text { Johnson } \\
\text { TW-2002 } \\
{[12]}\end{array}$ & $\begin{array}{l}\text { United } \\
\text { States }\end{array}$ & $\begin{array}{l}\text { Iowa Women's } \\
\text { Health Study }\end{array}$ & 27616 & 4.9 & $\begin{array}{l}\text { Patient } \\
\text { reported: } \\
\text { frequency; } \\
\text { baseline }\end{array}$ & $\begin{array}{c}\text { Breast cancer } \\
\text { incidence was } \\
\text { ascertained by linkage } \\
\text { to the State } \\
\text { Health Registry } \\
\text { of Iowa }\end{array}$ & 6 & 8 \\
\hline $\begin{array}{l}\text { Harris } \\
\text { RE-2003 } \\
{[13]}\end{array}$ & $\begin{array}{l}\text { United } \\
\text { States }\end{array}$ & $\begin{array}{c}\text { Women's } \\
\text { Health } \\
\text { Initiative } \\
\text { Observational } \\
\text { Study }\end{array}$ & 80741 & 44.81 & $\begin{array}{l}\text { Patient } \\
\text { reported: } \\
\text { duration; } \\
\text { baseline }\end{array}$ & $\begin{array}{l}\text { Initially by patient } \\
\text { report, Potential } \\
\text { cases were identified } \\
\text { through the } \\
\text { annual follow-up } \\
\text { questionnaires or } \\
\text { from nonroutine } \\
\text { contacts; all } \\
\text { examination reports } \\
\text { were reviewed }\end{array}$ & NA & 6 \\
\hline $\begin{array}{l}\text { Bardia } \\
\text { A-2011 } \\
{[14]}\end{array}$ & $\begin{array}{l}\text { United } \\
\text { States }\end{array}$ & $\begin{array}{l}\text { Iowa Women's } \\
\text { Health Study }\end{array}$ & 26580 & 5.1 & $\begin{array}{l}\text { Patient } \\
\text { reported: } \\
\text { frequency; } \\
\text { follow-up }\end{array}$ & $\begin{array}{c}\text { Identified by linking } \\
\text { to the Iowa Cancer } \\
\text { Registry }\end{array}$ & 13 & 7 \\
\hline $\begin{array}{l}\text { Hollestein } \\
\text { LM-2014 } \\
{[9]}\end{array}$ & Netherlands & $\begin{array}{l}\text { Eindhoven } \\
\text { Cancer } \\
\text { Registry and } \\
\text { the PHARMO } \\
\text { Record } \\
\text { Linkage } \\
\text { System }\end{array}$ & 109276 & 10.5 & $\begin{array}{l}\text { NA; duration; } \\
\text { baseline and } \\
\text { follow-up }\end{array}$ & NA & 4.4 & 7 \\
\hline $\begin{array}{l}\text { Kim } \\
\text { S-2015 } \\
{[10]}\end{array}$ & $\begin{array}{l}\text { United } \\
\text { States }\end{array}$ & Sister Study & 50884 & NA & $\begin{array}{l}\text { CATI-based } \\
\text { self-reported: } \\
\text { frequency, } \\
\text { duration; } \\
\text { baseline }\end{array}$ & $\begin{array}{c}\text { By pathology reports } \\
\text { or complete medical } \\
\text { report }\end{array}$ & 10 & 6 \\
\hline $\begin{array}{l}\text { Friis } \\
\text { S-2008 } \\
{[15]}\end{array}$ & Denmark & $\begin{array}{l}\text { Danish Diet, } \\
\text { Cancer and } \\
\text { Health cohort } \\
\text { study }\end{array}$ & 28695 & 3.9 & $\begin{array}{l}\text { Patient } \\
\text { reported: } \\
\text { frequency, } \\
\text { duration; } \\
\text { baseline and } \\
\text { follow-up }\end{array}$ & $\begin{array}{c}\text { Information on } \\
\text { cancer diagnoses } \\
\text { was obtained from } \\
\text { the Danish Cancer } \\
\text { Registry }\end{array}$ & 10 & 8 \\
\hline
\end{tabular}

(Continued) 


\begin{tabular}{|c|c|c|c|c|c|c|c|c|}
\hline Source & Location & $\begin{array}{c}\text { Cohort } \\
\text { Designation }\end{array}$ & $\begin{array}{l}\text { Total No. } \\
\text { of Patients }\end{array}$ & $\begin{array}{c}\text { Breast } \\
\text { cancer } \\
\text { incidence } \\
\text { (Cases/1000 } \\
\text { Person- } \\
\text { Years) }\end{array}$ & $\begin{array}{c}\text { Aspirin Use } \\
\text { Measure and } \\
\text { assessment } \\
\text { periods }\end{array}$ & $\begin{array}{c}\text { Breast Cancer } \\
\text { Screening Method }\end{array}$ & $\begin{array}{c}\text { Maximum } \\
\text { Follow- } \\
\text { up, y }\end{array}$ & NOS \\
\hline $\begin{array}{l}\text { Gierach } \\
\text { GL-2008 } \\
{[16]}\end{array}$ & $\begin{array}{l}\text { United } \\
\text { States }\end{array}$ & $\begin{array}{c}\text { National } \\
\text { Institutes of } \\
\text { Health-AARP } \\
\text { Diet and } \\
\text { Health Study }\end{array}$ & 127383 & 5.3 & $\begin{array}{l}\text { Patient } \\
\text { reported: } \\
\text { frequency; } \\
\text { baseline }\end{array}$ & $\begin{array}{l}\text { Initially identified } \\
\text { through probabilistic } \\
\text { linkage to eight state } \\
\text { cancer registries; } \\
\text { the cancer registry } \\
\text { ascertainment area } \\
\text { was recently expanded } \\
\text { to include three } \\
\text { additional states } \\
\text { to capture cancer } \\
\text { occurrence }\end{array}$ & 7.13 & 8 \\
\hline $\begin{array}{l}\text { Gill JK- } \\
2007[17]\end{array}$ & $\begin{array}{l}\text { United } \\
\text { States }\end{array}$ & $\begin{array}{l}\text { Multiethnic } \\
\text { Cohort }\end{array}$ & 98920 & NA & $\begin{array}{l}\text { Patient } \\
\text { reported: } \\
\text { duration; } \\
\text { baseline }\end{array}$ & $\begin{array}{l}\text { Identified through } \\
\text { linkages with the } \\
\text { Los Angeles County } \\
\text { Cancer Surveillance } \\
\text { Program, the State } \\
\text { of California Cancer } \\
\text { Registry, and the } \\
\text { Hawaii Tumor } \\
\text { Registry }\end{array}$ & 9 & 8 \\
\hline $\begin{array}{l}\text { Ready } \\
\text { A-2008 } \\
{[18]}\end{array}$ & $\begin{array}{l}\text { United } \\
\text { States }\end{array}$ & $\begin{array}{c}\text { Vitamins } \\
\text { And Lifestyle } \\
\text { study }\end{array}$ & 35323 & NA & $\begin{array}{l}\text { Patient } \\
\text { reported: dose; } \\
\text { baseline }\end{array}$ & $\begin{array}{l}\text { Ascertained through } \\
\text { annual linkage of } \\
\text { the VITAL cohort } \\
\text { database to the SEER } \\
\text { cancer registry }\end{array}$ & 10 & 8 \\
\hline $\begin{array}{l}\text { Bosco JL- } \\
2011 \text { [19] }\end{array}$ & $\begin{array}{l}\text { United } \\
\text { States }\end{array}$ & $\begin{array}{c}\text { Black } \\
\text { Women's } \\
\text { Health Study }\end{array}$ & 59000 & 2.3 & $\begin{array}{l}\text { Patient } \\
\text { reported: } \\
\text { duration; } \\
\text { baseline and } \\
\text { follow-up }\end{array}$ & $\begin{array}{c}\text { Reported on follow- } \\
\text { up questionnaires; to } \\
\text { date, medical records } \\
\text { or cancer registry data } \\
\text { have been obtained } \\
\text { for } 99.4 \% \text { of reported } \\
\text { cases }\end{array}$ & 12 & 7 \\
\hline $\begin{array}{l}\text { García } \\
\text { Rodríguez } \\
\text { LA-2004 } \\
{[20]}\end{array}$ & $\begin{array}{l}\text { United } \\
\text { Kingdom }\end{array}$ & $\begin{array}{l}\text { General } \\
\text { Practice } \\
\text { Research } \\
\text { Database }\end{array}$ & 23708 & 15.6 & $\begin{array}{l}\text { NA; dose, } \\
\text { duration; } \\
\text { baseline }\end{array}$ & $\begin{array}{l}\text { Identified patients } \\
\text { with a code of breast } \\
\text { cancer and manually } \\
\text { reviewed their } \\
\text { computerized patient } \\
\text { profiles }\end{array}$ & 6 & 8 \\
\hline $\begin{array}{l}\text { Eliassen } \\
\text { AH-2009 } \\
{[21]}\end{array}$ & $\begin{array}{l}\text { United } \\
\text { States }\end{array}$ & $\begin{array}{l}\text { Prospective } \\
\text { Nurses' } \\
\text { Health Study } \\
\text { II }\end{array}$ & 112292 & 1.1 & $\begin{array}{l}\text { Patient } \\
\text { reported: } \\
\text { frequency, } \\
\text { duration; } \\
\text { baseline and } \\
\text { follow-up }\end{array}$ & $\begin{array}{l}\text { Questionnaires and } \\
\text { medical records }\end{array}$ & 14 & 8 \\
\hline
\end{tabular}

Abbreviations: NA, not recorded or available; CATI, computer assisted telephone interview. 
Table 2: Confounding factors and methods for adjustment

\begin{tabular}{|c|c|c|c|}
\hline Source & $\begin{array}{l}\text { Method for } \\
\text { adjustment }\end{array}$ & $\begin{array}{c}\text { Risk } \\
\text { expression }\end{array}$ & Confounding factors \\
\hline $\begin{array}{l}\text { Jacobs EJ- } \\
2005[11]\end{array}$ & $\begin{array}{l}\text { Cox proportional } \\
\text { hazards model }\end{array}$ & RR & $\begin{array}{l}\text { Age, race, education, family history of breast cancer, personal history of } \\
\text { breast cysts, history of mammography, age at menarche, duration of oral } \\
\text { contraceptive use, parity, age at menopause, use of hormone replacement } \\
\text { therapy, weight change, BMI, alcohol consumption and duration of use of } \\
\text { other NSAID types }\end{array}$ \\
\hline $\begin{array}{l}\text { Johnson TW- } \\
2002[12]\end{array}$ & $\begin{array}{l}\text { Multivariate } \\
\text { adjustment }\end{array}$ & RR & $\begin{array}{c}\text { Age, BMI, estrogen use, family history of breast cancer, benign mammary } \\
\text { disease, multivitamin use, NSAID use, mammography, and waist: hip } \\
\text { ratio }\end{array}$ \\
\hline $\begin{array}{l}\text { Harris RE- } \\
2003[13]\end{array}$ & $\begin{array}{l}\text { Cox multivariate } \\
\text { regression }\end{array}$ & RR & Age \\
\hline
\end{tabular}

Age, education, family history of breast cancer, age at menarche, age at menopause, parity/age at first live birth, use of oral contraceptives, use of

Bardia Cox proportional

A-2011 [14] hazards models

$\begin{array}{lc}\text { Hollestein } & \text { Cox proportional } \\ \text { LM-2014 [9] } & \text { hazard model }\end{array}$

Kim S-2015 Cox regression

model

HR

Friis S-2008 Cox proportional

[15] hazards regression

RR

Gierach GL- Proportional

2008 [16] hazards model

Gill JK-2007 Multivariate Cox

[17] proportional

hazards model

$\begin{array}{lc}\text { Ready } & \text { Cox proportional } \\ \text { A-2008 [18] } & \text { hazards model }\end{array}$

Bosco JL- Cox proportional

2011 [19] hazards regression

RR

García

Rodríguez Multivariate

LA-2004 adjustment

OR

[20]

Eliassen AH- Cox proportional 2009 [21] hazards models

RR

HR

RR

HR
Age, race, BMI, family history of breast cancer, history of breast biopsy, mammogram within 2 years prior to baseline, age at menarche, age at first birth, age at menopause, history of surgical menopause, years of combined estrogen and progesterone hormone therapy, multivitamin use and alcohol use and use of other categories of NSAIDs

Education, BMI at age 18, vigorous activity, female hormone use, smoking and other NSAIDs

Age, calendar year, BMI, alcohol intake, smoking status, use of hormone replacement therapy, prior benign mammary disease, and others

Age at menarche, height, BMI at age 18, weight change since age 18, RR oral contraceptive use, parity and age at first birth, alcohol consumption, history of benign breast disease, family history of breast cancer

Abbreviations: RR: relative risk; HR: hazard ratios; OR: odd ratio; BMI: body mass index; NSAIDs: non-steroidal anti-inflammatory drugs. 
were adjusted for mammography ( 5 studies), smoking (3 studies), non-steroidal anti-inflammatory drug (NSAIDs) use (4 studies), physical activity (3 studies), contraceptive use (3 studies) or weight ( 3 studies). (Table 2 ).

\section{Comparisons of different dosages, frequencies and durations of aspirin intake}

The overall RRs of breast cancer with the highest, compared with the lowest dosages, duration, and frequency are shown in Figure 2A. There was no heterogeneity among studies of dosage $\left(P=0.936, I^{2}=\right.$ $0.0 \%)$ or duration $\left(P=0.138, I^{2}=34.9 \%\right)$; but significant heterogeneity was observed for frequency $\left(P=0.000, I^{2}=\right.$ $75.3 \%)$ and the overall usage of aspirin $\left(P=0.005, I^{2}=\right.$ $51.2 \%)$. With fixed effects models, no evidence of breast cancer risk was found in frequency $(\mathrm{RR}=0.94,95 \% \mathrm{CI}$ 0.89-1.00), dosage ( $R R=0.97,95 \%$ CI $0.85-1.10)$, or duration $(\mathrm{RR}=0.93,95 \%$ CI $0.85-1.02)$ of aspirin used. These results were similar when a random effects model was applied: frequency $(\mathrm{RR}=0.93,95 \% \mathrm{CI} 0.81-1.07)$, dose $(\mathrm{RR}=0.97,95 \% \mathrm{CI} 0.85-1.10)$ and duration $(\mathrm{RR}=$ 0.93 , 95\% CI 0.82-1.05) of aspirin intake (Figure 2B).

With a random effects model, a borderline inverse relationship was observed between overall aspirin intake (including dosage, frequency and duration) and breast cancer risk, with summarized $\mathrm{RR}=0.94(P=0.051,95 \%$ CI 0.87-1.01) (Figure 2B). This result was similar with that of the fixed effects model $(\mathrm{RR}=0.94,95 \%$ CI 0.90 0.99) (Figure 2A).

\section{Dose-response analysis}

As the number of included studies related to aspirin dosage and breast cancer risk was small (Table 3), and the information on breast cancer incidence (cases/1,000 person-years) was missing in the study of Ready A-2008 [18] (Table 1), dose-response analysis could not be performed for aspirin dose and breast cancer risk.

Studies of aspirin intake frequency (times/week) and breast cancer are presented in Table 4. The non-linear association of frequency and breast cancer risk had no significance in the spline model $(P=0.275)$. Therefore, a linear regression was built $(P=0.041$; Figure $3 \mathrm{~A})$. Breast cancer risk decreased as aspirin intake frequency increased. Breast cancer risk for 5 times/week aspirin intake was 0.97 (95\% CI 0.95-0.99). There was a trend of decreasing risk along with higher aspirin intake frequency $(\mathrm{RR}=0.95,95 \%$ CI $0.90-0.99$, for 10 times/week and RR $=0.90,95 \%$ CI $0.81-0.99$, for 20 times $/$ week).

Studies of aspirin intake years and breast cancer are presented in Table 5. The non-linear association of years of aspirin intake and breast cancer risk was significant in the cubic spline model $(P=0.014)$. However, a nonlinearity $(P=0.305)$ test did not refute the null hypothesis the linear model was available. Thus, a linear regression was conducted $(P=0.004$; Figure 3B). Breast cancer risk decreased as years of aspirin intake increased. If aspirin had been taken for 5 years, breast cancer risk was 0.86 (95\% CI 0.77-0.95). There was a trend of decreasing risk for more years of aspirin intake $(\mathrm{RR}=0.73,95 \% \mathrm{CI} 0.59$ 0.91 , for 10 years and $\mathrm{RR}=0.54,95 \%$ CI $0.35-0.82$, for 20 years). Table 5 shows that most of the included studies reported that the aspirin intake frequency was $\geq 2$ times per week for each duration.

\section{Sensitivity analysis}

Sensitivity analyses conducted by excluding one study at a time indicated that each individual dataset had no significant influence on the overall results (Figure 4). An alternative sensitivity analysis based on those studies with
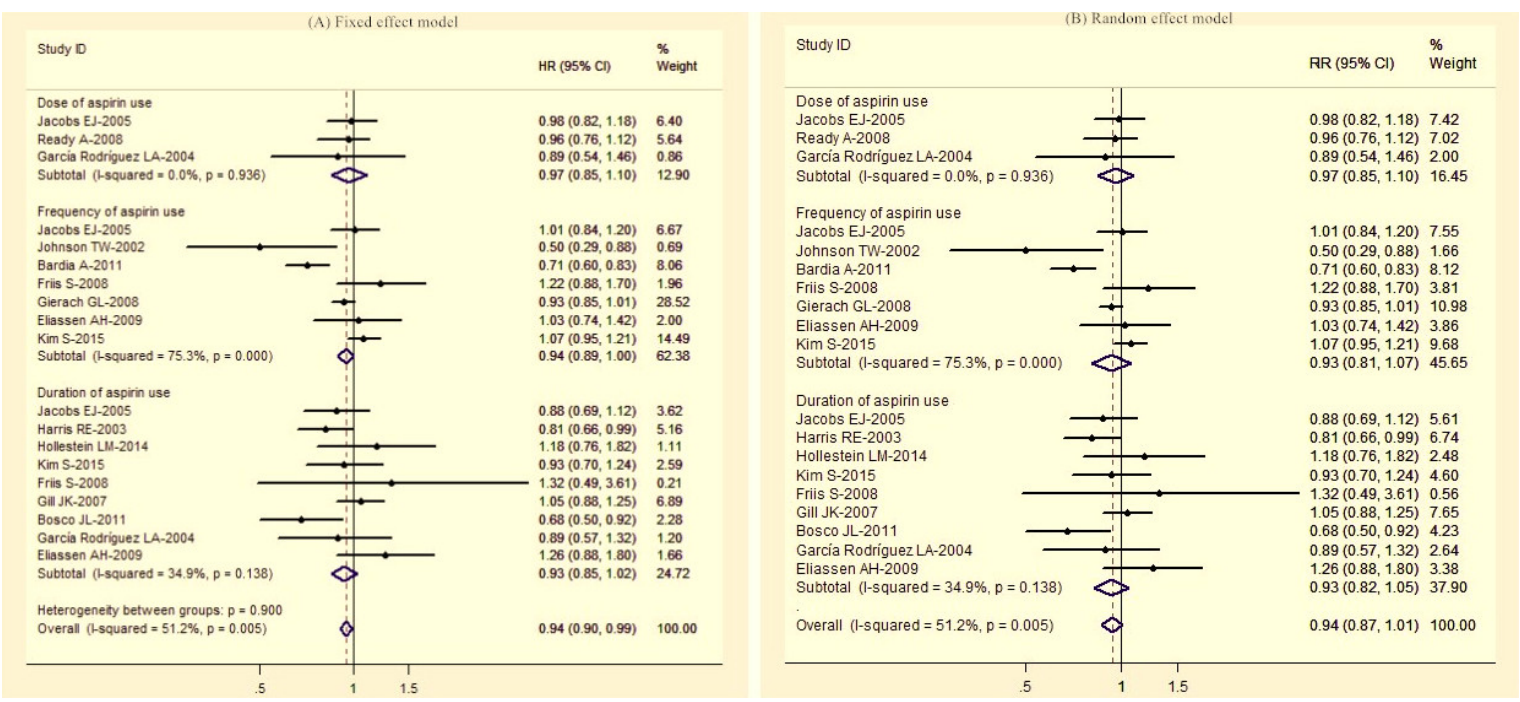

Figure 2: Relative risk of colorectal cancer for highest vs. lowest categories of aspirin use (dose, frequency and duration). 
Table 3: Epidemiological studies of aspirin dose (mg/week) and breast cancer

\begin{tabular}{lcccc}
\hline Author, year & Aspirin dose (mg/daily) & Dose midpoint (mg/daily) & RR & $\mathbf{9 5 \% ~ C I ~ f o r ~ R R ~}$ \\
\hline Jacobs EJ-2005 [11] & 0 & 0 & 1 & Reference \\
& $1-325$ & 162.5 & 1.11 & $1.01-1.22$ \\
Ready A-2008 [18] & $>325$ & 390 & 0.98 & $0.82-1.18$ \\
& 0 & 0 & 1 & Reference \\
García Rodríguez & $1-325$ & 162.5 & 0.99 & $0.80-1.23$ \\
LA-2004 [20] & $>325$ & 390 & 0.96 & $0.76-1.22$ \\
& 0 & 0 & 1 & Reference \\
& 75 & 75 & 0.67 & $0.51-0.89$ \\
& 150 & 150 & 0.96 & $0.65-1.41$ \\
\hline
\end{tabular}

Abbreviations: RR: relative risk; CI: confidence intervals.

a score of 7 or more was also conducted. When two studies with NOS ratings less than 7 (Harris RE-2003 [13] and Kim S-2015 [10]) were excluded, the pooled overall RR was 0.93 (95\% CI: 0.86-1.13), and the RR for frequency was 0.90 (95\% CI: 0.76-1.06) for the remaining studies.

We have summarized the assessment stage of aspirin exposure (e.g. at the cohorts' baselines, during follow-up periods or at both stages) in Table 1. We also performed sensitivity analysis by combining studies at different assessment stages of aspirin exposure, and found the results similar.

\section{Publication bias}

Funnel plots and statistical tests showed no publication bias for included reports of dosage (Figure 5A; Egger's test $P=0.227$; Begg's test $P=0.296$ ) or frequency (Figure 5B; Egger's test $P=0.755$; Begg's test $P=1.000$ ) and duration (Figure 5C; Egger's test $P=0.612$; Begg's test $P=0.602$ ).

\section{DISCUSSION}

Many epidemiologic studies exploring the association between breast cancer risk and aspirin intake have inferred inconsistent results. To obtain a better understanding of this issue, several meta-analyses have been published in recent years. Takkouche B [6] has drawn the conclusion that aspirin is related to decreased risk for breast cancer. Zhao YS [7] found that aspirin intake is related to a slight decrease in the development of breast cancer with a marginally statistically significant difference. Mangiapane S [5] found that aspirin might decrease breast cancer risk. However, these results must be interpreted carefully, as exposure categories have been defined heterogeneously among the studies which have weakened the validity of the pooled estimates. In addition, Mangiapane S [5] and Jacobo-Herrera NJ [22] have pointed out that the relationship between breast cancer and aspirin, dosage, time and frequency of aspirin use have yet to be established. Therefore, it is necessary to perform this dose-response meta-analysis with cohort design to offer a more confident and exhaustive solution to a possible inverse association between breast cancer risk and aspirin intake [22].

Our study confirmed a dose-response relationship between aspirin use and breast cancer risk. Our findings have demonstrated that a borderline significant inverse association exists between breast cancer risk and overall aspirin intake $(\mathrm{RR}=0.94 ; P=0.051 ; 95 \%$ CI: $0.87-$ 1.01). Additionally, the linear dose-response analysis displayed a potential association between the aspirin intake frequency and breast cancer risk $(\mathrm{RR}=0.97$ for 5 times/week aspirin use; RR $=0.95$ for 10 times/week aspirin use; $R R=0.90$ for 20 times/week), and also for the duration of aspirin intake and breast cancer risk (RR $=0.86$ for 5 years of aspirin use; $R R=0.73$ for 10 years of aspirin use; $R R=0.54$ for 20 years of aspirin use). We first comprehensively and quantitatively evaluated these relationships.

In regards to implications for clinical prevention, firstly an innovative finding from this research is the existence of a threshold effect between aspirin intake and breast cancer risk. Note that 5, 10 and 20 times/ week aspirin use only reduced 3\% (1-0.97), 5\% (1$0.95)$ and $10 \%$ (1-0.90) of breast cancer risk; 5, 10 and 20 years of aspirin use can reduce $14 \%$ (1-0.86), $27 \%(1-0.73)$ and $46 \%(1-0.54)$ of breast cancer risk, respectively. Secondly, it is worth considering whether it is cost-effective to use high-dose aspirin for the chemical prevention of breast cancer. Comprehensively considering high-dose aspirin intake may cause 
Table 4: Epidemiological studies of frequency of aspirin use (times/week) and breast cancer

\begin{tabular}{|c|c|c|c|c|}
\hline Author, year & $\begin{array}{c}\begin{array}{c}\text { Frequency of aspirin } \\
\text { use } \\
\text { (times/week) }\end{array} \\
\end{array}$ & $\begin{array}{l}\text { Frequency midpoint } \\
\text { (times/week) }\end{array}$ & $\mathbf{R R}$ & $95 \%$ CI for RR \\
\hline \multirow[t]{5}{*}{ Jacobs EJ-2005 [11] } & 0 & 0 & 1 & Reference \\
\hline & $0.25-3.50$ & 1.88 & 1.14 & $1.04-1.25$ \\
\hline & $3.75-7.25$ & 5.50 & 0.89 & $0.76-1.03$ \\
\hline & $7.50-14.75$ & 11.13 & 0.96 & $0.85-1.09$ \\
\hline & $\geq 15$ & 18.0 & 1.01 & $0.84-1.20$ \\
\hline \multirow[t]{5}{*}{ Johnson TW-2002 [12] } & 0 & 0 & 1 & Reference \\
\hline & $<1$ & 0.50 & 1.10 & $0.72-1.67$ \\
\hline & 1 & 1 & 1.71 & $0.93-3.13$ \\
\hline & $2-5$ & 3.50 & 0.97 & $0.59-1.58$ \\
\hline & $\geq 6$ & 7.20 & 0.50 & $0.29-0.88$ \\
\hline \multirow[t]{4}{*}{ Bardia A-2011 [14] } & 0 & 0 & 1 & Reference \\
\hline & $\leq 1$ & 0.50 & 0.87 & $0.76-0.99$ \\
\hline & $2-5$ & 3.50 & 0.78 & $0.66-0.92$ \\
\hline & $\geq 6$ & 7.20 & 0.71 & $0.60-0.83$ \\
\hline \multirow[t]{4}{*}{ Friis S-2008 [15] } & 0 & 0 & 1 & Reference \\
\hline & $0.50-0.75$ & 0.63 & 1.25 & $1.02-1.53$ \\
\hline & $1.0-6.0$ & 3.50 & 1.45 & $1.16-1.82$ \\
\hline & $7.0-42.0$ & 24.50 & 1.22 & $0.88-1.70$ \\
\hline \multirow[t]{4}{*}{ Gierach GL-2008 [16] } & 0 & 0 & 1 & Reference \\
\hline & $<1$ & 0.50 & 0.95 & $0.89-1.03$ \\
\hline & $1-6$ & 3.50 & 0.95 & $0.87-1.04$ \\
\hline & $\geq 7$ & 8.40 & 0.93 & $0.85-1.01$ \\
\hline \multirow[t]{4}{*}{ Kim S-2015 [10] } & 0 & 0 & 1 & Reference \\
\hline & $<4$ & 2 & 0.87 & $0.68-1.13$ \\
\hline & $4-6$ & 5 & 1.14 & $0.90-1.43$ \\
\hline & $\geq 7$ & 8.4 & 1.07 & $0.95-1.21$ \\
\hline \multirow[t]{5}{*}{ Eliassen AH-2009 [21] } & 0 & 0 & 1 & Reference \\
\hline & 1 & 0.50 & 1.01 & $0.78-1.30$ \\
\hline & $2-3$ & 2.50 & 1.18 & $0.87-1.60$ \\
\hline & $4-5$ & 4.50 & 0.64 & $0.35-1.16$ \\
\hline & $\geq 6$ & 7.20 & 1.03 & $0.74-1.42$ \\
\hline
\end{tabular}

Abbreviations: RR: relative risk; CI: confidence intervals.
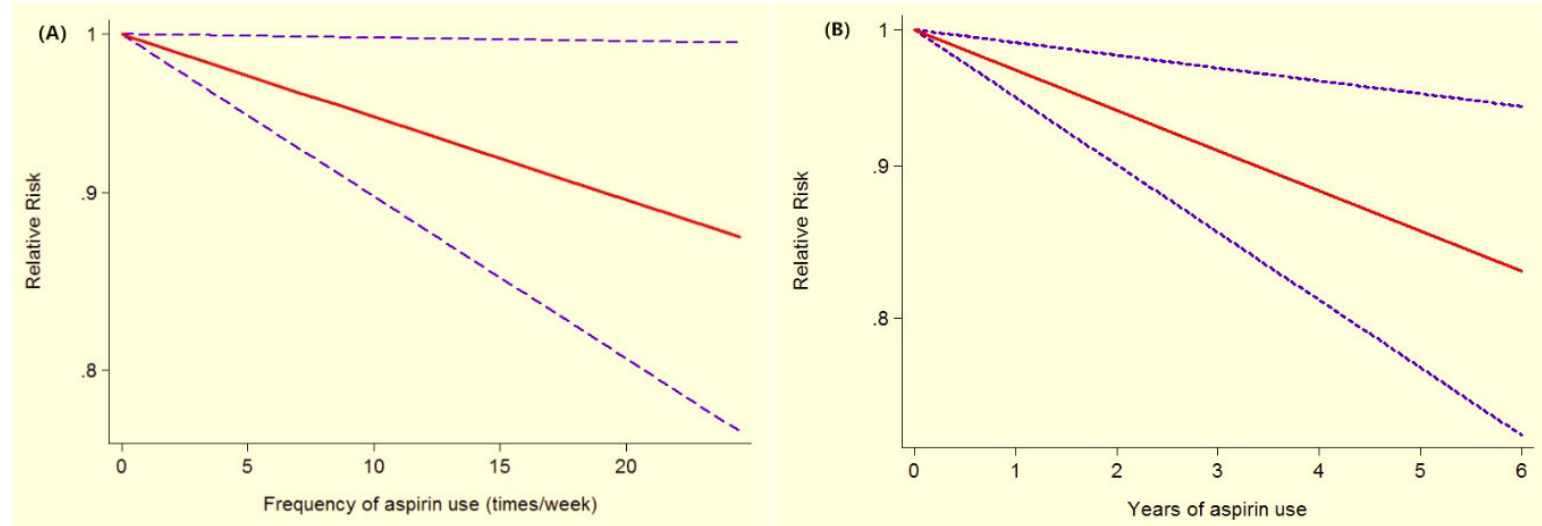

Figure 3: Association between frequency (years) of aspirin use and risk of breast cancer obtained by linear doseresponse meta-analyses. 
Table 5: Epidemiological studies of years of aspirin use and breast cancer

\begin{tabular}{|c|c|c|c|c|c|}
\hline Author, year & $\begin{array}{c}\text { Years of aspirin } \\
\text { use }\end{array}$ & $\begin{array}{c}\text { Frequency or dose } \\
\text { of aspirin use }\end{array}$ & Years midpoint & $\mathbf{R R}$ & 95\% CI for RR \\
\hline \multirow[t]{3}{*}{ Jacobs EJ-2005 [11] } & 0 & 0 & 0 & 1 & Reference \\
\hline & $<5$ & $\geq 1$ pills per day & 2.50 & 1.08 & $0.94-1.23$ \\
\hline & $\geq 5$ & $\geq 1$ pills per day & 6.0 & 0.88 & $0.69-1.12$ \\
\hline \multirow[t]{3}{*}{ Harris RE-2003 [13] } & 0-0.92 & $\begin{array}{c}\text { two or more tablets/ } \\
\text { week }\end{array}$ & 0.46 & 1 & Reference \\
\hline & $1-4$ & $\begin{array}{l}\text { two or more tablets/ } \\
\text { week }\end{array}$ & 2.5 & 0.90 & $0.72-1.13$ \\
\hline & $\geq 5$ & $\begin{array}{c}\text { two or more tablets/ } \\
\text { week }\end{array}$ & 6 & 0.81 & $0.66-0.99$ \\
\hline \multirow[t]{3}{*}{$\begin{array}{l}\text { Hollestein LM-2014 } \\
\text { [9] }\end{array}$} & $<2$ & $\leq 100 \mathrm{mg}$ daily & 1 & 1 & Reference \\
\hline & $2-6$ & $\leq 100 \mathrm{mg}$ daily & 4 & 1.12 & $0.90-1.40$ \\
\hline & $>6$ & $\leq 100 \mathrm{mg}$ daily & 7.2 & 1.18 & $0.76-1.82$ \\
\hline \multirow[t]{4}{*}{ Kim S-2015 [10] } & $<5$ & $\geq 2$ times per week & 2.5 & 1 & Reference \\
\hline & $5-9$ & $\geq 2$ times per week & 7.5 & 0.83 & $0.69-1.02$ \\
\hline & $10-20$ & $\geq 2$ times per week & 15 & 0.95 & $0.76-1.19$ \\
\hline & $>20$ & $\geq 2$ times per week & 24 & 0.93 & $0.70-1.24$ \\
\hline \multirow[t]{4}{*}{ Friis S-2008 [15] } & 0 & 0 & 0 & 1 & Reference \\
\hline & $<1$ & $\geq 1$ pills per month & 0.5 & 1.26 & $0.85-1.87$ \\
\hline & $1-3$ & $\geq 1$ pills per month & 2 & 1.14 & $0.60-2.15$ \\
\hline & $\geq 4$ & $\geq 1$ pills per month & 4.8 & 1.32 & $0.49-3.61$ \\
\hline \multirow[t]{4}{*}{ Gill JK-2007 [17] } & 0 & 0 & 0 & 1 & Reference \\
\hline & $\leq 1$ & $\geq 2$ times per week & 0.5 & 1.01 & $0.79-1.30$ \\
\hline & $2-5$ & $\geq 2$ times per week & 3.5 & 0.89 & $0.72-1.09$ \\
\hline & $\geq 6$ & $\geq 2$ times per week & 7.2 & 1.05 & $0.88-1.25$ \\
\hline \multirow[t]{6}{*}{ Bosco JL-2011 [19] } & 0 & absence & 0 & 1 & Reference \\
\hline & $<1$ & absence & 0.5 & 0.84 & $0.41-1.70$ \\
\hline & $1-1.9$ & absence & 1.5 & 0.37 & $0.05-2.66$ \\
\hline & $2-2.9$ & absence & 2.5 & 0.89 & $0.68-1.16$ \\
\hline & $3-4.9$ & absence & 4 & 0.84 & $0.59-1.19$ \\
\hline & $\geq 5$ & absence & 6 & 0.68 & $0.50-0.92$ \\
\hline \multirow[t]{5}{*}{$\begin{array}{l}\text { García Rodríguez LA- } \\
2004 \text { [20] }\end{array}$} & 0 & 0 & 0 & 1 & Reference \\
\hline & $0-0.9$ & 75-300 mg daily & 0.45 & 0.89 & $0.70-1.13$ \\
\hline & $1-1.9$ & $75-300 \mathrm{mg}$ daily & 1.45 & 0.69 & $0.42-1.10$ \\
\hline & $2-3.9$ & $75-300 \mathrm{mg}$ daily & 2.95 & 0.90 & $0.64-1.24$ \\
\hline & $\geq 4$ & 75-300 mg daily & 4.8 & 0.89 & $0.57-1.32$ \\
\hline \multirow[t]{3}{*}{ Eliassen AH-2009 [21] } & 0 & 0 & 0 & 1 & Reference \\
\hline & $<5$ & $\geq 2$ times per week & 2.5 & 1.03 & $0.84-1.26$ \\
\hline & $\geq 5$ & $\geq 2$ times per week & 6 & 1.26 & $0.88-1.80$ \\
\hline
\end{tabular}

Abbreviations: RR: relative risk; CI: confidence intervals; 1 pill or tablet was equal to $325 \mathrm{mg}$. 
bleeding complications [23], the optimal aspirin dose for preventing breast cancer may be in the scope of $<325 \mathrm{mg}$ per day, 2-7 times/week, along with long-term medication ( $>5$ years).

Though heterogeneity among studies was observed when comparing the highest and lowest frequency as well as the overall use of aspirin, sensitivity analyses indicated that the individual dataset had no significant influence on the overall results. When two studies with NOS ratings of less than 7 were excluded, the pooled RR was similar to that of the overall RR of all included studies. Thus, this meta-analysis's results were robust and confident. Two studies with NOS ratings less than 7 had lower quality in "comparability" and "follow up" than those of high quality studies, which reminded us that these two items were easily neglected in designing or reporting cohort studies. We also performed sensitivity analysis by combining studies at different assessment stages of aspirin exposure, and found the results similar. These results illustrate that the assessment method of aspirin exposure did not have any effect on the conclusions.

Our study has several strengths. It was conducted on 857,831 study participants with an average of 7.6 cases/1,000 person-years of breast cancer from 13 cohort studies. Using this massive database and extended followup duration, a stronger statistical power to detect and verify this hypothetical relationship can be generated with our analysis. Additionally, this dose-response design provides a better quantification of the relationship between specified amounts of aspirin intake and the risk of breast cancer, rather than only running a meta-analysis based on the comparison of the extreme categories of medication dosage (high versus low). To the best of our knowledge, this is the first study to explore a threshold effect between the frequency and duration of aspirin intake and breast cancer risk in order to guide the rational application of aspirin in breast cancer prevention.

Meanwhile, several limitations should also be acknowledged. Studies on different age, situ, locality,

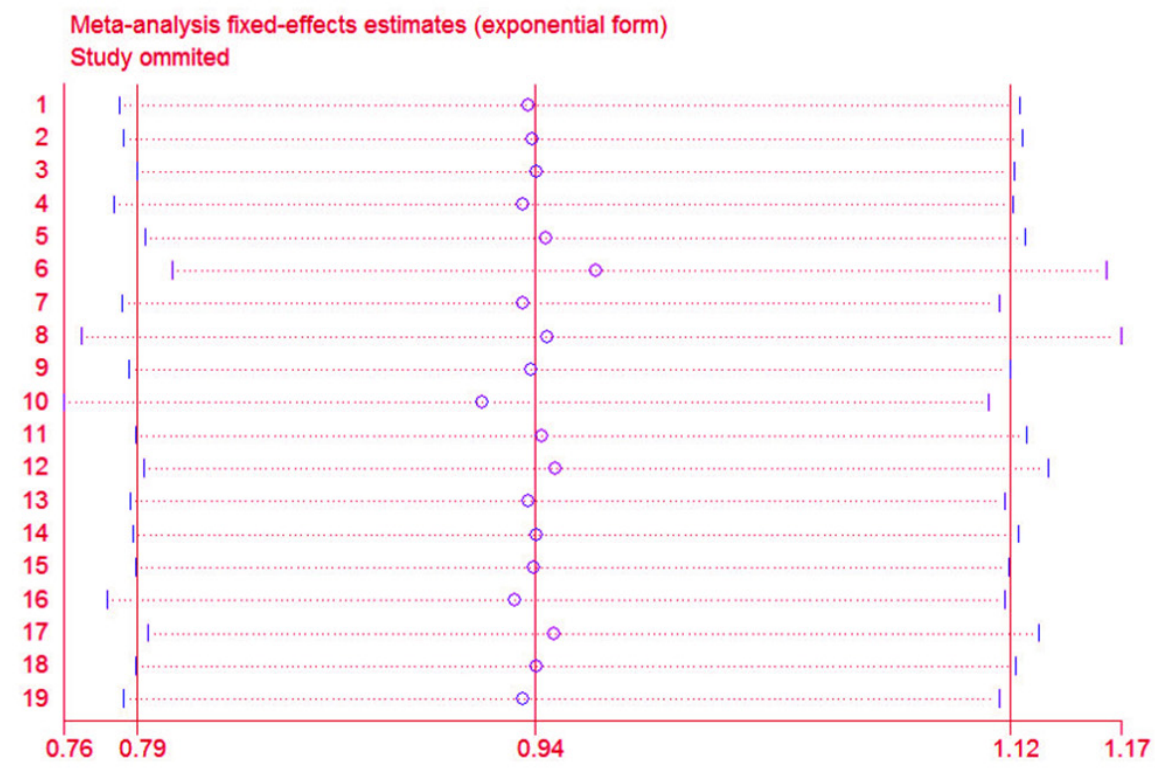

Figure 4: Sensitivity analyses through exclusion of 1 study at a time to reflect the influence of individual study to the overall results.
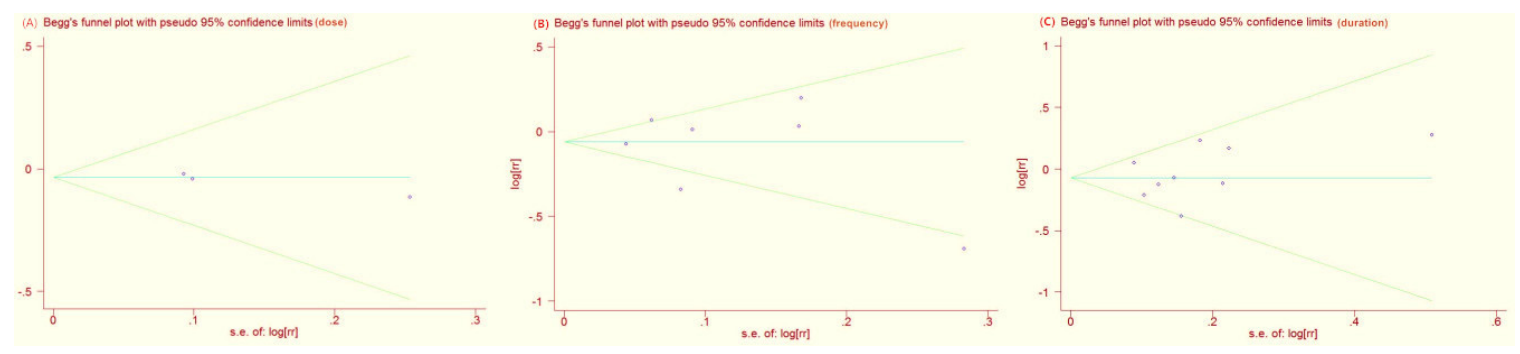

Figure 5: Begg's funnel plot with $95 \%$ confidence limits to detect publication bias (dose, frequency and duration). 
region and metastasis of breast cancer, estrogen receptor (ER) and progesterone receptor (PR) status are too limited to perform subgroup analysis. Also, although most of the results included in our study come from the completely adjusted models, other biases for the results may have been caused by adjusted models in studies adjusting for different covariates.

In conclusion, an innovative finding in this research is the threshold effect's existence between the frequency and duration of aspirin intake and breast cancer risk in the linear dose-response model. This suggests that the recommended frequency and duration of aspirin intake for breast cancer prevention is 2-7 times/week and $>5$ years, respectively. The potential benefits and harm associated with aspirin intake in different subgroups should be considered before translating this evidence into clinical applications.

\section{MATERIALS AND METHODS}

\section{Literature search}

A search of Medline, Embase and CENTRAL (Cochrane Library) databases from their inception until October 2016 was conducted to identify potentially eligible studies. We used the string ("aspirin' OR "acetylsalicylic acid" OR "ASA") AND "breast" AND ("neoplasm" OR "carcinoma" OR "cancer" OR "tumor" OR "adenocarcinoma" OR "sarcoma"). No language restrictions were imposed. The reference lists of all relevant studies were checked for further reports. For our paper, ethical approval was not necessary, as this study is a meta-analysis based on published data. The search strategy is attached in "Appendix 1".

\section{Inclusion and exclusion criteria}

Studies were included if: 1) they were a cohort study; 2) they consisted of an adult population ( $\geq 18$ years) exposed to different dosages, durations or frequencies of aspirin use with $\geq 3$ quantitatively measured exposure categories; 3) they defined breast cancer incidence as one of their endpoints; or 4) they reported original data including odds ratios (OR), relative risks (RR) or hazard ratios (HR), as well as $95 \%$ confidence intervals (CIs). The exclusion criteria for studies was those that were: 1) not full reports; or 2) cross-sectional, case-control designed, reviews, or comments; or 3) animal experimentation was used. The listed references were also checked for additional studies.

\section{Selection of reports to be studied}

To begin, one researcher (LLM) removed the duplicates from the reports, and then scanned the titles and abstracts of the citations (first scanning). This was done with the reference management software EndNote. Two researchers (LLM and ZJC) then cooperatively viewed the full text of all potentially eligible studies. If the literature did not meet the inclusion criteria, or if it met the exclusion criteria, they moved it into the appropriate folder with labels in EndNote X6. Disagreements between the two researchers were discussed and finally resolved by a collaborative effort involving the whole team.

\section{Exposure and outcome measurements}

Aspirin use measure methods (patient-reported or otherwise), assessment periods (at the cohorts' baselines, during follow-up periods or at both periods) and breast cancer screening methods (patient-reported, verified medical records, linkage with the registry or other methods) were summarized from the included cohort studies.

\section{Data extraction}

Two researchers (LLM and ZJC) used the EpiData 3.1 software to extract and enter the information from the final included reports by using a unified structure form. Extracted information included the first author's name, cohort designation, publication year, total number of participants, breast cancer incidence, aspirin use measure, breast cancer screening method, maximum follow-up years, adjustments, confounding factors, aspirin exposure categories (including dosage, frequency and duration), RR, HR or OR with $95 \%$ CIs of breast cancer for each aspirin use category.

To clarify the eligibility criteria and to ensure that the criteria could be applied consistently by more than one person, we pilot-tested a draft data abstraction form by randomly including 10 studies before beginning the formal data abstraction. When there was disagreement (i.e. kappa statistic $\leq 0.6$ ), two reviewers discussed and reached agreement. After doing this, we modified and supplemented the original eligibility criteria.

\section{Methodological quality}

The methodological quality of reports was assessed by Newcastle-Ottawa Scale (NOS) [24]. The NOS criteria includes subject selection (scores, 0-4), comparability of subject (scores, 0-2), and exposure or outcome (scores, $0-3$ ) [25], with the total score ranging from 0 to 9 . In our meta-analysis, a total score equal to or more than 7 indicated good quality.

\section{Statistical analysis}

The RRs were commonly used across studies. For transformation of RRs, HRs and odds ratios, ORs and HRs were considered RRs. The ORs could be converted into RRs using the formula $\mathrm{RR}=\mathrm{OR} /\left[\left(1-\mathrm{P}_{0}\right)+\left(\mathrm{P}_{0} * \mathrm{OR}\right)\right]$, in which $\mathrm{P}_{0}$ was the event incidence in the control group $[26$, 
27]. This formula had a limitation of underestimating the variance of the RRs derived from the ORs [28, 29]. Thus, a sensitivity analysis that excluded the one study with this transformation is presented.

First, meta-analysis with RR calculation (the lowest compared with the highest categories of aspirin intake) were used to evaluate the relationship between breast cancer risk and aspirin intake. When there was no heterogeneity, a fixed-effects model was performed to obtain a pooled estimate of effect; otherwise, a randomeffects model was applied. Following Greenland and Longnecker [30] and Orsini et al [31], we performed a dose-response analysis of aspirin effects on breast cancer risk. The distribution of cases, person-years and the adjusted RRs with 95\% CIs for at least 3 exposure categories were required. We chose the midpoint of the interval when aspirin categories' intervals were presented. When the upper level for the highest category was open-ended, the exposure doses were calculated as 1.2 times their exposure levels [25, 32]. A potential non-linear dose-response association by modeling dose, frequency or duration of aspirin intake was checked by restricted cubic splines with 3 knots at percentiles $25 \%$, $50 \%$, and $75 \%$ of the distribution, respectively. A linear regression model was also built. To test for nonlinearity, a likelihood ratio test was applied to contrast the model with both the linear and the spline terms and the model with the linear term only [33]. If the nonlinear model was invalidated, a linear model was be established to quantify the association of breast cancer risk and aspirin intake.

Statistical heterogeneity was calculated with Cochran's Q $(P<0.1)$ and $I^{2}$ tests (The $I^{2}$ test represents the percentage of total variation across studies) [34]. To evaluate the robustness of the overall results, sensitivity analyses were used by excluding one study at a time, and estimating the results based on those studies with a score $\geq 7$. This was done to investigate whether study quality had an influence on the overall association. Publication bias was evaluated by funnel plots, and quantified with Begg's and Egger's test $[35,36]$. When publication bias existed, we used the trim-and-fill method to evaluate the stability [37]. Stata version 11.0 software (StataCorp LP, College Station, TX, U.S.) was applied to perform all statistical analysis.

\section{Authors' contributions}

Liming Lu wrote the manuscript, and interpreted and performed the statistical analyses. Zehuai Wen designed this study and is in charge of the research project. Leiyu Shi and Zehuai Wen performed the critical revision and quality control. Jingchun Zeng and Liming $\mathrm{Lu}$ performed the literature search, data extraction and assessment of methodological quality. All authors revised the content, and approved the final version of the manuscript.

\section{ACKNOWLEDGMENTS}

This work received a grant from the National Key Technology R\&D Program for the 12th Five-year Plan of Ministry of Science and Technology, China (No. 2013BAI02B10) and Guangdong Natural Science Foundation (Project No. 2016A030310290).

\section{CONFLICTS OF INTERESTS}

The authors declare they have no competing interests.

\section{REFERENCES}

1. McGuire A, Brown JA, Malone C, McLaughlin R, Kerin MJ. Effects of age on the detection and management of breast cancer. Cancers (Basel). 2015; 7:908-929.

2. Muss HB, Berry DA, Cirrincione CT, Theodoulou M, Mauer AM, Kornblith AB, Partridge AH, Dressler LG, Cohen HJ, Becker HP, Kartcheske PA, Wheeler JD, Perez EA, et al. Adjuvant chemotherapy in older women with early-stage breast cancer. N Engl J Med. 2009; 360:2055-2065.

3. Pierce JP, Natarajan L, Marshall J, Messer K. Re: Dietary fat reduction and breast cancer outcome: interim efficacy results from the Women's Intervention Nutrition Study. J Natl Cancer Inst. 2007; 99:900, 900-901.

4. Holmes MD, Chen WY, Li L, Hertzmark E, Spiegelman D, Hankinson SE. Aspirin intake and survival after breast cancer. J CLIN ONCOL. 2010; 28:1467-1472.

5. Mangiapane S, Blettner M, Schlattmann P. Aspirin use and breast cancer risk: a meta-analysis and metaregression of observational studies from 2001 to 2005. Pharmacoepidemiol Drug Saf. 2008; 17:115-124.

6. Takkouche B, Regueira-Mendez C, Etminan M. Breast cancer and use of nonsteroidal anti-inflammatory drugs: a meta-analysis. J Natl Cancer Inst. 2008; 100:1439-1447.

7. Zhao YS, Zhu S, Li XW, Wang F, Hu FL, Li DD, Zhang WC, Li X. Association between NSAIDs use and breast cancer risk: a systematic review and meta-analysis. Breast Cancer Res Treat. 2009; 117:141-150.

8. Luo T, Yan HM, He P, Luo Y, Yang YF, Zheng H. Aspirin use and breast cancer risk: a meta-analysis. Breast Cancer Res Treat. 2012; 131:581-587.

9. Hollestein LM, van Herk-Sukel MP, Ruiter R, de Vries E, Mathijssen RH, Wiemer EA, Stijnen T, Coebergh JW, Lemmens VE, Herings RM, Stricker BH, Nijsten T. Incident cancer risk after the start of aspirin use: results from a Dutch population-based cohort study of low dose aspirin users. Int J Cancer. 2014; 135:157-165.

10. Kim S, Shore DL, Wilson LE, Sanniez EI, Kim JH, Taylor JA, Sandler DP. Lifetime use of nonsteroidal antiinflammatory drugs and breast cancer risk: results from a prospective study of women with a sister with breast cancer. BMC Cancer. 2015; 15:960. 
11. Jacobs EJ, Thun MJ, Connell CJ, Rodriguez C, Henley SJ, Feigelson HS, Patel AV, Flanders WD, Calle EE. Aspirin and other nonsteroidal anti-inflammatory drugs and breast cancer incidence in a large U.S. cohort. Cancer Epidemiol Biomarkers Prev. 2005; 14:261-264.

12. Johnson TW, Anderson KE, Lazovich D, Folsom AR. Association of aspirin and nonsteroidal anti-inflammatory drug use with breast cancer. Cancer Epidemiol Biomarkers Prev. 2002; 11:1586-1591.

13. Harris RE, Chlebowski RT, Jackson RD, Frid DJ, Ascenseo JL, Anderson G, Loar A, Rodabough RJ, White E, McTiernan A. Women's Health Initiative. Breast cancer and nonsteroidal anti-inflammatory drugs: prospective results from the Women's Health Initiative. Cancer Res. 2003; 63:6096-6101.

14. Bardia A, Olson JE, Vachon CM, Lazovich D, Vierkant RA, Wang AH, Limburg PJ, Anderson KE, Cerhan JR. Effect of aspirin and other NSAIDs on postmenopausal breast cancer incidence by hormone receptor status: results from a prospective cohort study. Breast Cancer Res Treat. 2011; 126:149-155.

15. Friis S, Thomassen L, Sørensen HT, Tjønneland A, Overvad K, Cronin-Fenton DP, Vogel U, McLaughlin JK, Blot WJ, Olsen JH. Nonsteroidal anti-inflammatory drug use and breast cancer risk: a Danish cohort study. Eur J Cancer Prev. 2008; 17:88-96.

16. Gierach GL, Lacey JV Jr, Schatzkin A, Leitzmann MF, Richesson D, Hollenbeck AR, Brinton LA. Nonsteroidal anti-inflammatory drugs and breast cancer risk in the National Institutes of Health-AARP Diet and Health Study. Breast Cancer Res. 2008; 10:R38.

17. Gill JK, Maskarinec G, Wilkens LR, Pike MC, Henderson $\mathrm{BE}$, Kolonel LN. Nonsteroidal antiinflammatory drugs and breast cancer risk: the multiethnic cohort. Am J Epidemiol. 2007; 166:1150-1158.

18. Ready A, Velicer CM, McTiernan A, White E. NSAID use and breast cancer risk in the VITAL cohort. Breast Cancer Res Treat. 2008; 109:533-543.

19. Bosco JL, Palmer JR, Boggs DA, Hatch EE, Rosenberg L. Regular aspirin use and breast cancer risk in US Black women. Cancer Causes Control. 2011; 22:1553-1561.

20. García Rodríguez LA, González-Pérez A. Risk of breast cancer among users of aspirin and other anti-inflammatory drugs. Br J Cancer. 2004; 91:525-529.

21. Eliassen AH, Chen WY, Spiegelman D, Willett WC, Hunter DJ, Hankinson SE. Use of aspirin, other nonsteroidal antiinflammatory drugs, and acetaminophen and risk of breast cancer among premenopausal women in the Nurses' Health Study II. Arch Intern Med. 2009; 169:115-121.

22. Jacobo-Herrera NJ, Perez-Plasencia C, Camacho-Zavala E, Gonzalez GF, Urrutia EL, Garcia-Castillo V, Zentella-Dehesa
A. Clinical evidence of the relationship between aspirin and breast cancer risk (review). ONCOL REP. 2014; 32:451.

23. Collaborative meta-analysis of randomised trials of antiplatelet therapy for prevention of death, myocardial infarction, and stroke in high risk patients. BMJ. 2002; 324:71-86.

24. Stang A. Critical evaluation of the Newcastle-Ottawa scale for the assessment of the quality of nonrandomized studies in meta-analyses. EUR J EPIDEMIOL. 2010; 25:603-605.

25. An N. Oral Contraceptives Use and Liver Cancer Risk: A Dose-Response Meta-Analysis of Observational Studies. Medicine (Baltimore). 2015; 94:e1619.

26. Zhang J, Yu KF. What's the relative risk? A method of correcting the odds ratio in cohort studies of common outcomes. JAMA. 1998; 280:1690-1691.

27. Willi C, Bodenmann P, Ghali WA, Faris PD, Cornuz J. Active smoking and the risk of type 2 diabetes: a systematic review and meta-analysis. JAMA. 2007; 298:2654-2664.

28. McNutt LA, Wu C, Xue X, Hafner JP. Estimating the relative risk in cohort studies and clinical trials of common outcomes. AM J EPIDEMIOL. 2003; 157:940-943.

29. Greenland S. Model-based estimation of relative risks and other epidemiologic measures in studies of common outcomes and in case-control studies. AM J EPIDEMIOL. 2004; 160:301-305.

30. Greenland S, Longnecker MP. Methods for trend estimation from summarized dose-response data, with applications to meta-analysis. AM J EPIDEMIOL. 1992; 135:1301-1309.

31. Orsini N, Bellocco R, Greenland S and Others. Generalized least squares for trend estimation of summarized doseresponse data. STATA J. 2006; 6:40.

32. Ye X, Fu J, Yang Y, Chen S. Dose--Risk and Duration-Risk Relationships between Aspirin and Colorectal Cancer: A Meta-Analysis of Published Cohort Studies. 2013.

33. Bagnardi V, Zambon A, Quatto P, Corrao G. Flexible metaregression functions for modeling aggregate dose-response data, with an application to alcohol and mortality. AM J EPIDEMIOL. 2004; 159:1077-1086.

34. Higgins JP, Thompson SG, Deeks JJ, Altman DG. Measuring inconsistency in meta-analyses. BMJ. 2003; 327:557-560.

35. Begg CB, Mazumdar M. Operating characteristics of a rank correlation test for publication bias. BIOMETRICS. 1994; 50:1088-1101.

36. Egger M, Davey SG, Schneider M, Minder C. Bias in metaanalysis detected by a simple, graphical test. BMJ. 1997; 315:629-634.

37. Duval S, Tweedie R. Trim and fill: A simple funnel-plotbased method of testing and adjusting for publication bias in meta-analysis. BIOMETRICS. 2000; 56:455-463. 